2016

\title{
Justice Reinvestment and the State of State Sentencing Reform
}

\author{
Michael M. O'Hear \\ Marquette UniversityLaw School, michael.ohear@marquette.edu
}

Follow this and additional works at: http://scholarship.law.marquette.edu/facpub

Cart of the Law Commons

Publication Information

Published as Michael M. O'Hear, Justice Reinvestment and the State of State Sentencing Reform, 29

Fed. Sent'g Rep. 1 (2016). (C) 2016 by the Regents of the University of California on behalf of the Vera Institute of Justice. Copying and permissions notice: Authorization to copy this content beyond fair use (as specified in Sections 107 and 108 of the U. S. Copyright Law) for internal or personal use, or the internal or personal use of specific clients, is granted by the Regents of the University of California on behalf of the Vera Institute of Justice for libraries and other users, provided that they are registered with and pay the specified fee via Rightslink ${ }^{\circledast}$ on Caliber (http://caliber.ucpress.net/) or directly with the Copyright Clearance Center, http://www.copyright.com.

\section{Repository Citation}

O'Hear, Michael M., "Justice Reinvestment and the State of State Sentencing Reform" (2016). Faculty Publications. Paper 679. http://scholarship.law.marquette.edu/facpub/679

This Article is brought to you for free and open access by the Faculty Scholarship at Marquette Law Scholarly Commons. It has been accepted for inclusion in Faculty Publications by an authorized administrator of Marquette Law Scholarly Commons. For more information, please contact 


\section{E D I TOR S ' O B S E R V A T I O N S}

\section{Justice Reinvestment and the State of State Sentencing Reform}

\section{MICHAEL M. O'HEAR}

Professor, Marquette Law School

Editor, Federal Sentencing Reporter

Fourteen years ago, I edited an FSR issue that surveyed recent developments in state sentencing reform. That year, 2002, seemed to be a transitional time. In the I990s, nearly all new laws pointed in one direction-greater toughness. However, in the wake of the 200 I recession, several cash-strapped states adopted reforms that were intended to curtail imprisonment growth and rein in corrections budgets. A few optimistic commentators were welcoming a new era, seeing in the reforms a fresh and promising political dynamic: fiscal conservatives were joining with liberals to produce thoughtful, constructive reform-a striking departure from the aggressive partisanship and tough-on-crime posturing that dominated sentencing policy in the I990s. Providing an overview of these trends, my Editor's Observations in 2002 were entitled "The New Politics of Sentencing."

With the hindsight of fourteen years, the proclamation of a new era seems to have been both partly prescient and partly premature. In one sense, the trends starting to become apparent in a few states between 2000 and 2002 did expand across the country and still seem very much in evidence today. Many conservatives have embraced the cause of decarceration and have worked across the aisle to enact reforms diverting nonviolent offenders from prison and creating opportunities for those already in prison to earn an accelerated release. As with the first wave of reforms adopted around the time of the 200I recession, more recent changes have typically also been justified by reference to state fiscal pressures-pressures that intensified sharply following the 2007 recession. Yet, for all of the reform activity, remarkably little decarceration has actually occurred. On December 3I, 2000, America's prison population stood at about I.4 million; fourteen years later, the population numbered close to I.6 million-a net increase. ${ }^{2}$ Modest reductions did begin after 2009, when the national prison population hit its peak, but most of this drop came from a single state, California, which was forced to decarcerate by court order. ${ }^{3}$

The disappointing performance of the post-2000 reforms reflected certain limitations that may have been inherent to the new sentencing politics. In my 2002 Editor's Observations, I pointed to several potential challenges for the emerging movement, including that short-term fiscal pressures might not prove a sound foundation for long-term improvements in sentencing and corrections policy; that reforms might be overly focused on nonviolent drug offenders, neglecting other categories of offenders who constituted a larger share of the prison population; and that giving greater discretion to sentencing judges and corrections officials - a central objective of reformers - might not lead to much softening of punishment in practice. To varying degrees, each of these concerns has been borne out by experience.

The post-2000 sentencing reform movement found its culmination in the Justice Reinvestment Initiative (JRI). The concept of "justice reinvestment" was first developed in a 2003 paper by Susan Tucker and Eric Cadora. ${ }^{4}$ They suggested that if imprisonment could be reduced, the resulting monetary savings might be reinvested in social services and infrastructure development in high-crime, highincarceration neighborhoods; such reforms, they argued, might more effectively protect public safety over the long run than the prevailing tough-minded, enforcement-based strategies. After reinvestmentinspired reforms had success in a handful of states, the concept was refined into the JRI. Promoted and partly financed by the federal government, and supported by a small group of other agencies, the JRI included a formalized process for reviewing and improving state sentencing and corrections policies. ${ }^{5}$

Federal Sentencing Reporter, Vol. 29, No. I, pp. I-5, ISSN 1053-9867, electronic ISSN 1533-8363. (C) 2016 Vera Institute of Justice. All rights reserved. Please direct requests for permission to photocopy or reproduce article content through the University of California Press's Reprints and Permissions web page, http://www.ucpress.edu/journals.php?p=reprints. DOI: I0.I525/fsr.20I6.29.I.I. 
More than half of the states have at least attempted the JRI process, with most ultimately adopting significant reform legislation. Putting the extraordinary California experience to one side, a good case could be made that the JRI has been the state sentencing reform story of the past decade.

The present issue of FSR thus focuses on the JRI in more detail. Articles recount the JRI experience in two specific states, offer more general reflections on the present and future of the JRI as a national phenomenon, and compare the JRI experiences of the United States and the United Kingdom. In these Editor's Observations, I provide an overview of these contributions, but first offer a few thoughts of my own, assessing in a very preliminary way how well JRI has responded to the challenges I identified in 2002 for the then-emerging "new politics of sentencing." 6

\section{JRI as the New Politics of Sentencing}

In the early 2000s, as burgeoning corrections budgets were attracting increasing levels of critical attention and inspiring bipartisan reform efforts, one key question was whether fiscal motivations would truly support the right kind of sentencing and corrections changes-reforms that would bring down imprisonment and keep it down in sustainable ways. Government fiscal planning is notoriously biased to the short term; the logic of political accountability through frequent elections practically guarantees a quick-fix mentality on the part of governors and legislators. For that reason, there seemed a real risk that efforts to reduce corrections budgets would head in a counterproductive direction. For instance, programming for offenders might be cut, community supervision positions left unfilled, or necessary construction to ease prison overcrowding deferred. Such policy choices might save money in the short run, but could have an adverse effect on recidivism rates and so eventually lead to greater demand for correctional resources in the long run. Likewise, simply releasing prisoners more quickly without investing additional resources in reentry planning and community supervision might yield short-term dividends, but would be unlikely to achieve sustainable reductions in the prison population.

To its credit, the officially sanctioned JRI process is designed to produce durable, systematic reform, not just quick fixes. ${ }^{7}$ Although fiscal pressures may initially bring policymakers to the table, once they get there, they will find a process that includes extensive data collection, analysis of leading criminal justice cost drivers, and development of multiple policy options. The process is also designed to build on itself over time through reinvestment of the savings achieved by virtue of reduced incarceration. The money should not all go to plugging short-term holes in the state budget, but should instead support the development and expansion of evidence-based programs to reduce recidivism. In theory, at least, the "reinvestment" component of the JRI responds effectively to concerns that budget-minded sentencing and corrections reforms will prove penny-wise, but pound-foolish.

The reality of the JRI, however, does not always live up to the theory. The reinvestment piece has been particularly problematic. Some JRI states have adopted no reinvestment plan at all, while others committed only a small percentage of savings to recidivism-reduction initiatives. Moreover, what reinvestment commitments were made at the outset often proved less than firm and reliable, as some states later chose to redirect savings to general budgetary purposes. Indeed, more generally, the JRI has suffered from a lack of sustained commitment by policymakers; recommended reforms have sometimes been disregarded, or adopted and then later either repealed or undercut through new waves of ad hoc, toughon-crime legislation adopted after the passing of the fiscal crisis.

A second key question for the new politics of sentencing was whether reforms would reach much beyond the nonviolent drug offenders. Over the long course of American history, public attitudes toward drugs have regularly swung back and forth from permissive to intolerant. ${ }^{8}$ The post-2000 sentencing reform push coincided with a shift away from that period of extreme intolerance commonly termed the War on Drugs. Harsh drug sentencing laws thus became an easy target for reformers looking to reduce incarceration. Indeed, much reform was structured around distinctions between "violent" and "nonviolent" offenders, with breaks given to the nonviolent offenders to ensure adequate prison space for the violent. In particular, nonviolent drug offenders benefitted from a rapid proliferation of drug courts and other programs aiming to divert drug-involved criminals from incarceration into treatment.

Whatever the merit of these initiatives, however, they can have only a modest direct impact on national imprisonment rates. Putting the federal system to one side, drug offenders - even at the height of the War on Drugs - have always been a much smaller portion of the national prison population than those serving time for violent crimes. (In 2000, they constituted about 2I percent of state prisoners, whereas violent offenders constituted about 49 percent. ${ }^{9}$ ) Moreover, many of those nominally in prison on drug convictions are serving sentences that are still driven in some significant way by violence concerns (e.g., a prior conviction for an assaultive crime or possession of a gun during the current drug 
offense). Reforms targeting the wholly nonviolent drug offender will reach only a quite limited number of those being sent away for long prison terms.

More meaningful decarceration will require taking chances on some offenders who may seem, at first blush, riskier. However, upon closer inspection, many of those who arguably fall on the wrong side of the violent/nonviolent divide are not so dangerous after all, taking into account the age and specific circumstances of their offenses, their post-offense behavior, and the availability of effective treatment and supervision in the community.

Although there is nothing in the JRI process that explicitly limits reform to nonviolent offenders, there has been a marked tendency in practice for JRI states to focus on relatively easy, noncontroversial diversions, especially for drug and property offenses and purely technical violations of probation or parole. Perhaps no reform has been so widely embraced in the JRI states as has been the development of new systems of graduated, community-based sanctions for technical violations, which serve as an alternative to full-blown revocation and imprisonment. Also common has been reduced sentencing ranges for low-dollar property offenses, marijuana offenses, and drug offenses in school zones. From a mass incarceration standpoint, the JRI has been going after the low-hanging fruit. There is, of course, some value to this, but continued progress will require bolder reform.

A third key question in 2002 was whether reform would rely chiefly on increasing the sentencing discretion of judges and the release discretion of corrections officials, or would more directly mandate changes in practice. The tough-on-crime legislation of the late twentieth century often curtailed official discretion, as through mandatory minimum prison terms or "truth in sentencing," so it made some sense to think that increasing discretion in the early twenty-first century would help to bring down excessive incarceration. However, this strategy would only work to the extent that front-line officials actually agreed the prevailing, incarceration-heavy practices should change. On the other hand, if they were generally pleased with the status quo, then simply giving them more power would accomplish little.

The first reform wave did emphasize the restoration of discretion, with one very prominent exception: Proposition 36, adopted by California voters in 2000, which mandated probation and treatment in lieu of incarceration for certain categories of nonviolent drug offenders. Proposition 36 was an alternative to the drug court model, which relied heavily on official discretion to decide whom to divert into treatment, and which bestowed upon judges considerable power to use incarceration as a penalty for failures in treatment. Whereas the drug court model left front-line officials with plenty of room to maintain a basically punitive approach to drug crime, Proposition 36 mandated a sharper break from past practice.

For its part, the JRI process does not explicitly favor discretion over mandatory change, but the JRI's emphasis on obtaining broad support across different government agencies may implicitly favor discretion; agencies are unlikely to support reforms that significantly reduce their power. (The push for broad-based consensus also helps to explain why the JRI has focused so much on the low-hanging decarceration fruit.) Certainly, in practice, much of the focus of JRI has been on developing new options for sentencing judges and corrections officials, without necessarily mandating the use of those options. At the same time, some reforms have imposed meaningful new limitations on the severity of punishments, such as caps on the length of incarceration that can be imposed for technical violations of probation or parole, and reductions in the maximum penalties for some low-level drug and property crimes. More aggressive use of firm constraints like these may be necessary to achieve more impressive reductions in incarceration.

\section{JRI: Recent Developments and Future Prospects}

In this issue of FSR, our contributors touch on these points and many other notable aspects of the JRI. Two articles cover the JRI experience in specific states. Mark Bergstrom and Kristofer Bret Bucklen tell the Pennsylvania story. ${ }^{\text {IO }}$ The Keystone State adopted legislation emerging from the JRI process in 20I2, with the centerpiece being new measures to reduce the level of imprisonment from technical violations of parole. Bergstrom and Bucklen report that Pennsylvania is on track to meet its population-reduction goals, but that reinvestment has been slower and smaller than anticipated. Nonetheless, state leaders have been sufficiently pleased with their experience that they recently initiated a new round of JRI analysis and discussion to focus on front-end criminal justice reforms, including sentencing.

In her article, Rebecca Murdock focuses on North Carolina, which adopted JRI reforms in 20II. ${ }^{\text {II }}$ In particular, she describes changes to habitual offender laws, a new sentencing option that permits accelerated release based on the completion of programming in prison, and a new requirement for postrelease supervision. She notes surprisingly low utilization of new sentencing options (both a new habitual offender option and the new accelerated-release opportunity). Among other things, her article 
highlights the importance of plea-bargaining dynamics in determining the extent to which new sentencing options will be used in practice.

In their article, James Austin, Todd Clear, and Garry Coventry offer a more general assessment of the American JRI experience. ${ }^{\mathrm{I} 2}$ They unpack in more detail the original Tucker-Cadora concept of justice reinvestment and show how the JRI in practice has deviated from that ideal. They find no evidence that the JRI states, as a whole, have done a significantly better job at reducing their prison populations than the non-JRI states, and they observe that the JRI has so far produced very little "reinvestment," as Tucker and Cadora understood the term. They call for a refocused, reinvigorated JRI-one that emphasizes "justice" rather than public safety, and that aims for much larger reductions in imprisonment.

Faye Taxman also considers the national experience more broadly. ${ }^{\mathrm{I}}$ Among other sources of disappointment with the JRI, she notes that the initiative could and should do much more to build treatment capacity for mental illness and substance abuse disorders, which could lead to a significant reduction in recidivism rates. Taxman also calls for a new focus on programs and agencies outside the justice system, which could help people to avoid becoming involved in the system in the first place.

In their article, Judith A. Greene and Vincent Schiraldi intriguingly ask whether the JRI strategy, "with its top-down reliance on technocratic data analysis and elite consensus-building, should be preferred to a vigorous bottom-up approach that flexes grassroots muscle and elicits broad public engagement, as well as litigation, to build powerful political demands for systemic change."I4 They note that the nation's three decarceration champs, California, New York, and New Jersey, have made their gains without going through the JRI process. Greene and Schiraldi then take a closer look at New York City, which has been the main driver of New York State's overall imprisonment decline. The City has achieved sharp declines in both incarceration and crime, powerfully demonstrating that cutting the former does not necessarily lead to more of the latter.

Kevin Wong and Kris Christmann provide an international perspective. ${ }^{15}$ They describe justice reinvestment efforts in the United Kingdom, drawing contrasts with the American JRI experience using an original framework for assessing the scale, capacity, and outcomes of justice reinvestment programs. They lament the piecemeal development of justice reinvestment in the United Kingdom through a disparate set of pilot programs. Federal financial and technical support for the JRI, combined with the relative autonomy of American state governments, have permitted more rapid development on this side of the Atlantic. Still, Americans might find something to learn from the U.K. programs, some of which have arguably remained truer to the original social-justice spirit of justice reinvestment than has the American JRI.

Finally, Darren Wheelock and I report results from our survey research on voter attitudes toward the criminal justice system in Wisconsin. ${ }^{16}$ Although our article does not directly concern the JRI, it does highlight some of the political dynamics that have made bolder JRI reforms so challenging. For instance, we find significant differences in the attitudes of Republican and Democratic voters. Despite the support of high-profile Republicans like Newt Gingrich and Grover Norquist for decarceration, we find that Democrats are much more likely than Republicans to give a high priority to cutting costs in the criminal justice system. Indeed, Republicans tend to place much greater importance on giving criminals "the punishment they deserve" than to cost-cutting. Republicans are also more likely than Democrats to criticize how well the system is currently ensuring deserved punishment. Such results suggest that rankand-file Republicans may not have climbed aboard the reform bandwagon to the same extent as party elites. These fault lines, of course, seem to echo the intraparty divisions displayed so vividly in connection with the presidential campaign of Donald Trump.

\section{Conclusion}

Concerns about the fiscal burdens of mass incarceration are not unique to the new millennium, but two successive recessions followed by uneven, shallow recoveries devastated state budgets and gave new political traction to calls for cost-cutting sentencing reforms. The JRI established a systematic process for translating the new political dynamics into durable improvements to state justice systems, rather than just short-sighted quick fixes. JRI reforms seem generally well-designed to help states use their correctional resources more efficiently, with fewer resources-including fewer prison beds-devoted to low-risk offenders. The movement has proven much less effective at reducing the overall scale of imprisonment, not to mention rebuilding the human resources and physical infrastructure of highcrime, high-incarceration neighborhoods, as the originators of justice reinvestment hoped.

Achieving large-scale reductions in imprisonment likely requires a commitment to that as an end in itself, in contrast to the ends of cost cutting, recidivism reduction, and efficiency that have been exalted by the JRI. A social commitment to deep decarceration, in turn, may require a new "new politics of 
sentencing" - one that is less technocratic and more grounded in compassion; less oriented to achieving consensus among justice system agencies and insiders, including those who have an interest in maintaining the mass incarceration status quo, and more oriented to serving the needs of those on whom the system acts, their families, and their neighborhoods. The limitations of the old "new politics" become clearer year by year, but the path to genuinely new approaches remains uncertain.

\section{Notes}

$1 \quad 15$ Fed. Sent. Rep. 3 (2002).

2 These figures come from the on-line prisoner data tool of the Bureau of Justice Statistics, http://www.bjs.gov/ index.cfm?ty=nps.

3 Between 2009 and 2014, the national prison population dropped by 53,962, while California's dropped by 35,187-equal to about two-thirds of the overall decline.

4 Susan B. Tucker \& Eric Cadora, Justice Reinvestment: To Invest in Public Safety by Reallocating Justice Dollars to Refinance Education, Housing, Healthcare, and Jobs (2003), available at https://www.opensocietyfoundations. org/sites/default/files/ideas_reinvestment.pdf.

5 In the interests of full disclosure, one participating agency was the Vera Institute of Justice, which publishes this journal. The views expressed in this article are, of course, my own and not necessarily those of the Vera Institute of Justice or FSR.

6 This discussion is adapted from Michael O'Hear, Treading Water: Mass Incarceration and Sentencing Reform in the New Millennium, ch. 4 (forthcoming 2017).

7 For a description of the full, seven-step process, see Nancy Lavigne et al., Justice Reinvestment Initiative State Assessment Report 13-17 (2014).

8 See, e.g., Michael Tonry, Thinking About Crime: Sense and Sensibility in American Penal Culture 82-83 (2004).

9 Paige M. Harrison \& Allen J. Beck, U.S. Dep't of Justice, Prisoners in 2001, at 13 (2002).

10 Justice Reinvestment in Pennsylvania-Another Opportunity for Bold Action, 29 Fed. Sent. Rep. 15-21 (2016).

11 The Justice Reinvestment Act in North Carolina and its Impact on Sentencing, 29 Fed. Sent. Rep. 39-46 (2016).

12 Reinvigorating Justice Reinvestment, 29 Fed. Sent. Rep. 6-14 (2016).

13 Justice Reinvestment: Extending the Framework to Non-Justice Efforts, 29 Fed. Sent. Rep. 52-57 (2016)

14 Better by Half: The New York City Story of Winning Large-Scale Decarceration while Improving Public Safety, 29 Fed. Sent. Rep. 22-38 (2016).

15 Justice Reinvestment: "Motherhood and Apple Pie?" Matching Ambition to Capacity and Capability, 29 Fed. Sent. Rep. 58-67 (2016).

16 Public Attitudes Toward Punishment, Rehabilitation, and Reform: Lessons from the Marquette Law School Poll, 29 Fed. Sent. Rep. 47-51 (2016). 